\title{
DYSPHAGIA DUE TO ANTERIOR CERVICAL OSTEOPHYTOSIS: CASE REPORT
}

\author{
DISFAGIA POR OSTEOFITOSE CERVICAL ANTERIOR: RELATO DE CASO CLÍNICO
}

\author{
DISFAGIA POR OSTEOFITOSIS CERVICAL ANTERIOR: RELATO DE CASO CLÍNICO \\ Frederico Miguel Santos Silva Marouez Correia', João Paulo de Sousa Goucha Jorge², Ana Sofia Teixeira Neves'1, \\ Gabriel Fillpe Gonçalves Xavier ${ }^{1}$, Marco Miguel Barroso de Oliveira', José Eduardo Paiva Ferreira ${ }^{1}$
}

\begin{abstract}
The objective of this study is to highlight the possibility of dysphagia induced by anterior cervical osteophytes. When not diagnosed early this condition may be responsible for complications such as severe dysphagia and potential lung aspiration, especially in elderly patients. Analysis of a case report of a 72-year old woman who presented cervical pain and progressive dysphagia. Imaging studies have shown anterior cervical osteophytosis and multilevel degenerative changes in the cervical spine. The patient underwent surgical excision of the cervical anterior osteophytes (C4, C5 and C6) and C5/C6 arthrodesis through anterior approach. The postoperative period was uneventful and symptoms resolved within 2 weeks. Early diagnosis and treatment led to complete resolution, avoiding late and serious complications associated with this pathology in the geriatric population, especially severe and progressive dysphagia and risk of pulmonary aspiration, and the consequent morbidity and mortality associated. A multidisciplinary approach is essential for the correct assessment of this condition.
\end{abstract}

Keywords: Spinal osteophytosis; Cervical vertebrae; Deglutition disorders; Osteophyte; Pain; Diagnosis, differential; Arthrodesis; Prognosis.

\section{RESUMO}

O objetivo do trabalho é salientar a possibilidade de disfagia induzida por osteofitose cenvical anterior. Quando não diagnosticada precocemente essa afecção pode ser responsável por complicações como disfagia grave e aspiração pulmonar, sobretudo nos doentes idosos. Análise de caso clínico de doente do sexo feminino com 72 anos de idade que apresentava dor cervical e disfagia progressiva. Foram realizados exames de imagem que revelaram osteofitose cervical anterior e alterações degenerativas em diversos níveis. A paciente foi submetida à excisão cirúrgica dos osteófitos cervicais anteriores (C4, C5 e C6) e à artrodese de C5-C6 por acesso cervical anterior. O período pós-operatório decorreu sem complicações com remissão dos sintomas em duas semanas. O diagnóstico e tratamento precoces permitiram a resolução completa, evitando as complicações tardias e graves associadas a essa patologia na população geriátrica, sobretudo disfagia grave e progressiva e risco de aspiração pulmonar, com a consequente morbimortalidade a elas associada. A abordagem multidisciplinar é fundamental para a avaliação correta desse quadro.

Descritores: Osteofitose vertebral; Vértebras cenicais; Transtornos de deglutição; Osteófito; Dor; Diagnóstico diferencial; Artrodese; Prognóstico.

\section{RESUMEN}

El objetivo de este trabajo es salientar la posibilidad de disfagia inducida por osteofitosis cervical anterior. Cuando no es diagnosticada precozmente esta afección puede ser responsable por complicaciones como disfagia grave y aspiración pulmonar, sobre todo en los enfermos ancianos. Análisis de caso clínico de enfermo del sexo femenino con 72 años de edad que presentaba dolor cervical y disfagia progresiva. Fueron realizados exámenes de imagen que revelaron osteofitosis cervical anterior y alteraciones degenerativas en diversos niveles. La paciente fue sometida a escisión quirúrgica de los osteófitos cervicales anteriores (C4, C5 e C6) y a la artrodesis de C5-C6 por acceso cervical anterior. El período postoperatorio transcurrió sin complicaciones con remisión de los síntomas en dos semanas. El diagnóstico y tratamiento precoces permitieron la resolución completa, evitando las complicaciones tardías y graves asociadas a esa patología en la población geriátrica, sobre todo disfagia grave y progresiva y riesgo de aspiración pulmonar, con la consiguiente morbimortalidad a ellas asociada. El abordaje multidisciplinario es fundamental para la evaluación correcta de ese cuadro.

Descriptores: Osteofitosis vertebral; Vértebras cenvicales; Trastornos de deglución; Osteófito; Dolor; Diagnóstico diferencial; Artrodesis; Pronóstico.

\section{INTRODUCTION}

The differential diagnosis of dysphagia is extensive. In anterior cervical hyperosteophytosis, the excessive formation of marginal bone spurs (osteophytes) along the anterior cervical spine is a common but rare symptomatic finding, mostly seen in the elderly. ${ }^{1,2}$ The majority of these patients are asymptomatic, and the condition is rarely associated with upper airway obstruction. ${ }^{1,3}$

The clinical condition occurs in cases of degenerative disc disease, as part of the physiological or accelerated ageing process, post trauma, post laminectomy syndromes, or in cervical spondylosis, although it is most frequently seen in syndromes like diffuse idiopathic skeletal hyperostosis (DISH), also known as Forestier's disease..$^{2-10}$

The initial therapeutic approach is conservative and includes diet modification, postural corrections, muscle relaxers, anti-reflux and non-steroid anti-inflammatory drugs. Surgery is indicated only in severe cases with large osteophytes, when conservative treatment fails.

1. Hospital Espirito Santo de Évora, Portugal.

2. Hospital da Cruz Vermelha Portuguesa, Portugal.

Study conducted at the Hospital Espirito Santo de Évora, Portugal.

Correspondence: Av. Dr Francisco Sá Carneiro 40. 7000-757. Évora, Portugal. fcorreia1@ hotmail.com 
The aim of this case report is to draw attention to how frequently anterior cervical osteophytes can cause dysphagia, emphasizing the risks of life-threatening complications that may arise from this condition.

We report the case of a 72-year old woman who presented a 6-year history of cervical pain, stiffness and progressive dysphagia. The patient was fully investigated, and underwent surgery following the failure of conservative management.

\section{RESULTS}

A 72-year old female with arterial hypertension and obesity was referred to our outpatient clinic complaining of progressive dysphagia and radiating cervical pain and stiffness. Symptoms began approximately 6 years prior to our Orthopaedic consultation, when the patient first noticed difficulty swallowing solid food, and was seen by her general practitioner (GP). An X-ray of the cervical spine was taken and showed anterior cervical hyperosteophytosis with degenerative changes at several levels of the cervical spine. In order to rule out other causes of dysphagia, an upper Gl endoscopy was performed that revealed a diffuse hyperemic gastric mucosa from the antrum. The patient was prescribed analgesics and dietary measures to improve her main symptoms.

One year later, due to persistence of the symptoms, she seen again by her GP who requested a cervical spine CT scan. This exam showed severe and enlarged anterior osteophytes of the cervical spine with mechanical compression over the cervical esophagus.

Following this exam the patient was lost to follow-up for five years.

In October 2010, the patient was referred to our Department for progressive dysphagia, with increased difficulty swallowing liquids as well as aggravation of her cervical pain and stiffness. There was no history of weight loss, pneumonia, shortness of breath, hoarseness or trismus. Neurologic and physical examinations were uneventful and all hematology and biochemistry blood tests were within the normal range.

Apart from an extensive anterior osteophyte formation at $\mathrm{C} 4 / 5$ and $\mathrm{C} 5 / 6$ seen on the lateral X-ray, an MRI of the neck showed esophageal compression due to the anterior osteophytes, and spinal cord compression at $\mathrm{C} 4 / 5$ and $\mathrm{C} 5 / 6$ due to degenerative disc disease (Figures 1, 2 and 3).

In view of these findings, the patient underwent surgical excision of the anterior osteophytes ( $\mathrm{C} 4, \mathrm{C} 5$ and $\mathrm{C} 6$ ) and $\mathrm{C} 5 / 6$ decompression and fusion with a cage and autologous bone graft, through an anterior paramedian cervical approach. The surgical procedure and post-operative period were uneventful, with no postoperative complications. (Figures 4 and 5) The symptoms resolved within two weeks, and the postoperative radiographs showed that the osteophytes from C4 to C6 had been completely excised and the esophageal compression was relieved.

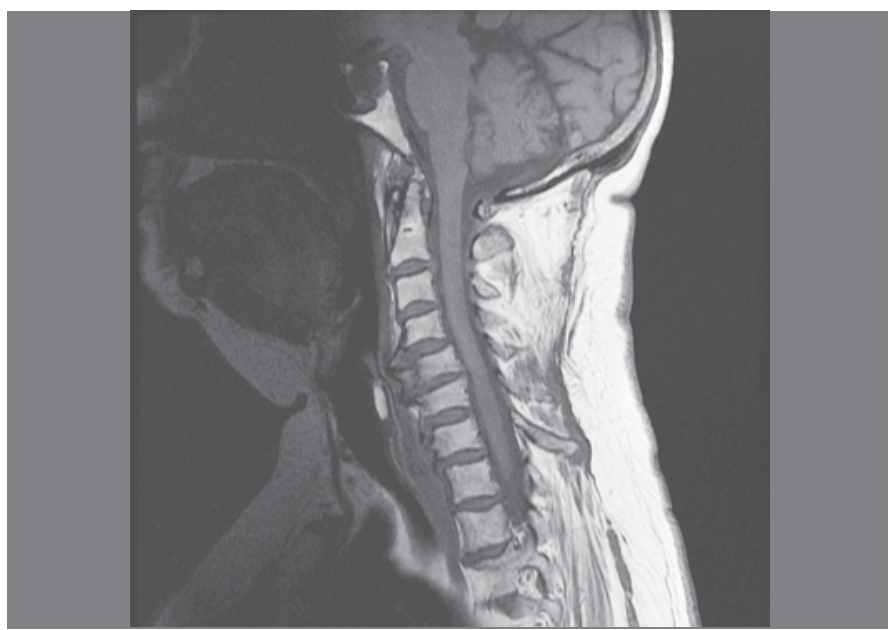

Figure 1. Pre-operative Sagittal cervical spine MRI (T1 FSE) showing C4-C5-C6 anterior osteophyte formation and C5-C6 degenerative disc.

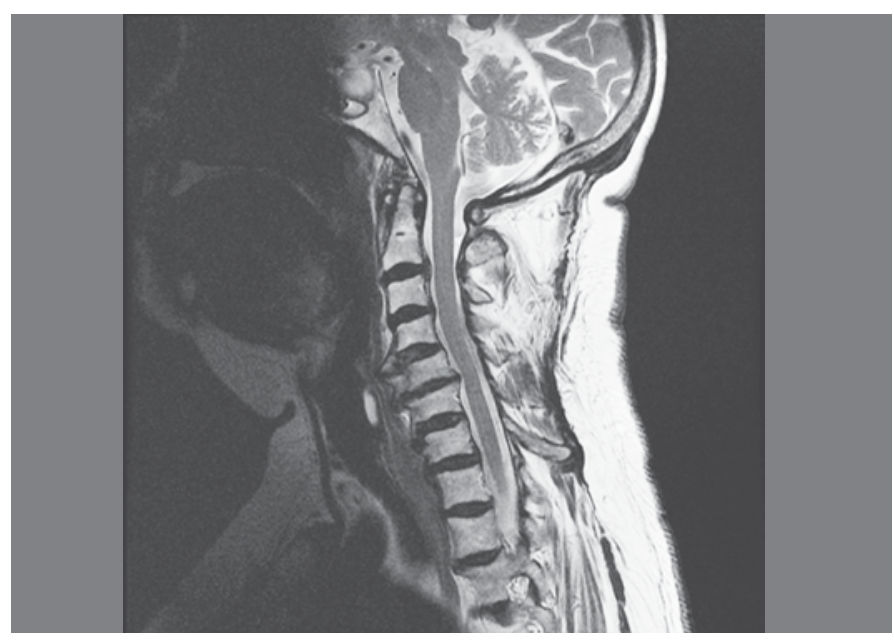

Figure 2. Sagittal cervical spine MRI (T2 frFSE).

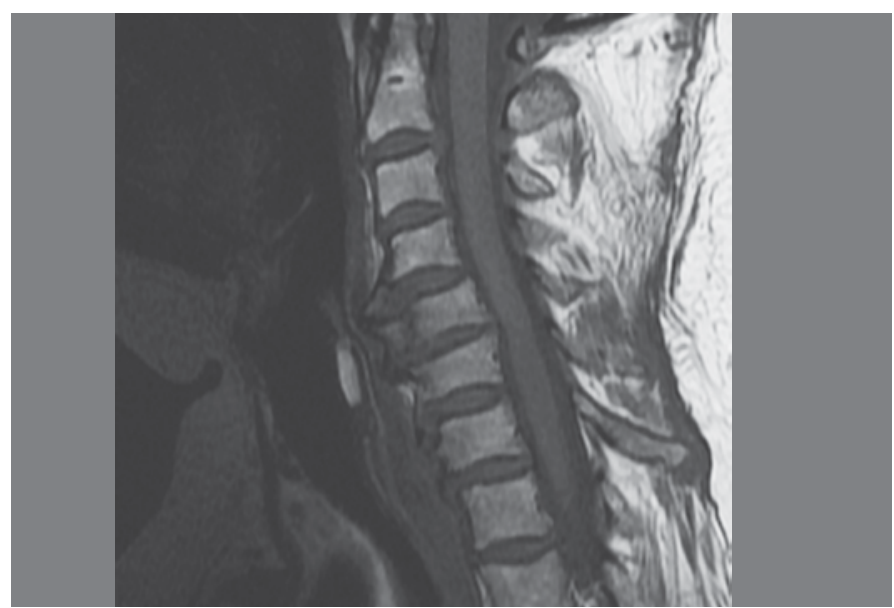

Figure 3. Sagittal cervical spine MRI (Zoom).

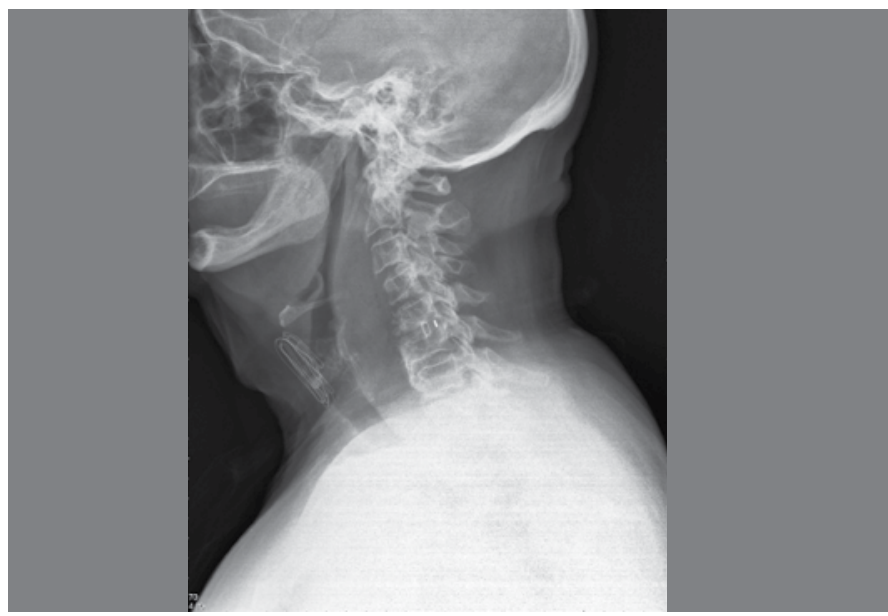

Figure 4. Postoperative cervical spine lateral $X$-ray showed absence of the osteophytes, normalization of the normal structure and correct position of the cage.

\section{DISCUSSION}

Dysphagia is a common complaint in routine clinical general practice. A complete clinical history and physical examination are necessary as part of the work up of these patients with many other comorbidities, but an understanding of the physiopathology, and of the different investigations available, is essential for a complete diagnosis. 


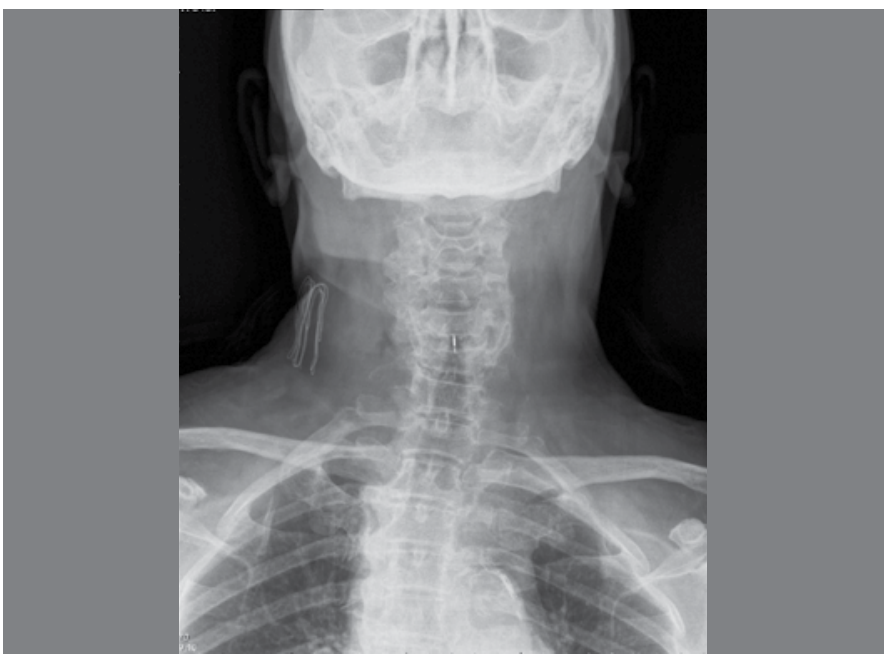

Figure 5. Postoperative cervical spine AP X-ray.

Diffuse idiopathic skeletal hyperostosis (DISH) is the most frequent cause of large, symptomatic anterior cervical osteophytes. This inflammatory condition is defined by: (a) presence of flowing calcification and ossification along the anterolateral aspect of at least four contiguous vertebral body-intervertebral, with or without associated localized pointed excrescences at the intervening vertebral body-intervertebral disc junctions; (b) relative preservation of intervertebral disc height in the vertebral segment involved, and absence of extensive radiographic changes of degenerative disc disease; and (c) absence of apophyseal joint bony ankylosis and sacroiliac joint erosion, sclerosis, or intra-articular osseous fusion.11 Our patient did not have involvement of four contiguous vertebral bodies, and presented with degenerative disc disease and posterior cervical arthritis.

Three theories have been postulated to explain the mechanism of dysphagia caused by osteophytes. First, large osteophytes cause direct mechanical compression on the esophagus or hypopharynx. Second, dysphagia may even be caused by small osteophytes, if they are located at fixed points of the oesophagus (cricoid cartilage at level C6). Third, it may be caused by a local inflammatory reaction resulting in compressive edema.

The pathogenesis of dysphagia caused by hypertrophic cervical osteophytes is hypothesized to be the result of direct compression of the aerodigestive tract and associated nerves, as well as local inflammation that leads to mucosal edema, formation of adhesion, fibrosis, and cricopharyngeus muscle spasms. The cause of local inflammation is thought to be the result of repetitive mechanical trauma caused by the constant dynamic movement of the pharyngolaryngoesophageal complex over the large hypertrophic hyperostosis. Typically, osteophytes that cause dysphagia are in the C5 cervical interspace.

In the case reported here, the symptoms resolved after surgical excision of the osteophytes that were compressing the cervical esophagus, and once the post operative edema had cleared up, the patient was able to resume her swallowing abilities.

We therefore feel that the most likely cause of dysphagia may have been the mechanical effect of the bone spurs on the esophagus, but we were surprised that the displacement was not reported in the upper Gl endoscopy.

\section{FINAL CONSIDERATIONS}

It is important to be aware of this diagnosis in cases of progressive dysphagia. Early diagnosis and treatment enable resolution ad integrum of symptoms, avoiding serious complications associated with this pathology. Elderly patients are particularly at risk, especially from severe and progressive dysphagia with an increased risk of pulmonary aspiration and subsequent associated morbidity and mortality.

A multidisciplinary approach is essential for the correct assessment and work up of these patients.

\section{ACKNOWLEDGMENTS}

The authors thank Prof. Jorge Mineiro for reviewing the manuscript.

All authors declare no potential conflict of interest concerning this article.

\section{REFERENCES}

1. Kissel P, Youmans JR. Posttraumatic anterior cervical osteophyte and dysphagia: surgical report and literature review. J Spinal Disord. 1992;5(1):104-7.

2. Hughes TA, Wiles CM, Lawrie BW, Smith AP. Case report: dysphagia and sleep apnoea associated with cervical osteophytes due to diffuse idiopathic skeletal hyperostosis (DISH). J Neurol Neurosurg Psychiatry. 1994;57(3):384.

3. McGarrah PD, Teller D. Posttraumatic cervical osteophytosis causing progressive dysphagia. South Med J. 1997:90(8):858-60.

4. Gamache FW Jr, Voorhies RM. Hypertrophic cervical osteophytes causing dysphagia. A review. J Neurosurg. 1980;53(3):338-44.

5. Calisaneller T, Ozdemir O, Tosun E, Altinors N. Dysphagia due to diffuse idiopathic skeletal hyperostosis. Acta Neurochir (Wien). 2005:147(11):1203-6.

6. Nelson RS, Urquhart AC, FaciszewskiT. Diffuse idiopathic skeletal hyperostosis: a rare cause of Dysphagia, airway obstruction, and dysphonia. J Am Coll Surg. 2006;202(6):938-42
7. Ortega-Martínez M, Cabezudo JM, Gómez-Perals LF, Fernández-Portales I.Anterior cervical osteophyte causing dysphagia as a complication of laminectomy. $\mathrm{Br} \mathrm{J}$ Neurosurg. 2005;19(2):174-8

8. Srinivas P, George J. Cervical osteoarthropathy: an unusual cause of dysphagia. Age Ageing. 1999;28(3):321-2

9. Resnick D, Shaul SR, Robins JM. Diffuse idiopathic skeletal hyperostosis (DISH): Forestier's disease with extraspinal manifestations. Radiology. 1975:115(3):513-24.

10. Matan AJ, Hsu J, Fredrickson BA. Management of respiratory compromise caused by cervical osteophytes: a case report and review of the literature. Spine J. 2002;2(6):456-9.

11. De Jesus-Monge WE, Cruz-Cuevas El. Dysphagia and lung aspiration secondary to anterior cervical osteophytes: a case report and review of the literature. Ethn Dis. 2008;18(2 Suppl 2):S2-137-40. 